\title{
THE STUDY OF DEPENDENCE OF THE PRENYL FLAVONOIDS CONTENT IN THE HOP DRY EXTRACT ON TEMPERATURE PARAMETERS OF ITS OBTAINING
}

\author{
O.O.Dobrovolnyi \\ SIC "Borshchahivskiy Chemical Pharmaceutical Plant", PJSC, Kyiv
}

Key words: hop cones; extractives; prenyl flavonoids; estrogenic activity; evaporation, drying

When developing the technology of a dry extract of hop cones as an active pharmaceutical ingredient with the estrogen-like action the key factors that can affect the quality of the finished product have been investigated. Taking into account that hop prenyl flavonoids are relatively unstable compounds and under certain thermodynamic conditions are prone to transformation the influence of the temperature parameters such as evaporation and drying of the hop liquid extract on the content of xanthohumol $(X)$, isoxanthohumol (IX), 8-prenylnaringenin (8-PN) and 6-prenylnaringenin (6-PN) in the dry extract has been researched. The objects of the research were the samples of the hop liquid extract after extraction of the raw material and the dry extract after evaporation and drying. The extraction of hop cones has been carried out by the two-step filtration method extraction with the pretreatment of the raw material with steam. At the first step the hop raw material was extracted with n-hexane with the subsequent extraction of the extraction cake with water-alcohol solvent at the second step. The aqueous-ethanol extract was evaporated and dried in vacuum to prevent possible destruction of prenyl flavonoids. The quantitative content of xanthohumol, isoxanthohumol, 8-prenylnaringenin and 6-prenylnaringenin has been determined by HPLC in the samples of liquid and dry extracts. It has been found that sparing conditions of evaporation and drying used has led to decreasing the quantitative content of $X, I X, 8-P N$ and 6-PN in the dry extract compared with the content of these compounds in the water-alcohol liquid extract in the range of $14,16,8,14 \%$, respectively.

The use of plants containing phytoestrogens, with its historical length may be compared with the history of medicine in general. One of the most interesting sources of compounds with the estrogen-like action is a hop cones. The results of the pharmacological studies of hop extracts indicate the relationship between estrogenic activity of the objects and the fraction of prenyl flavonoids: xanthohumol (X), desmethylxanthohumol (DMX), isoxanthohumol (IX), 8-prenylnaringenin (8-PN) and 6-prenylnaringenin (6-PN). It has been found that the marked estrogenic activity of the polyphenolic fraction belongs to 8-PN and characterizes this compound as the most powerful pharmacological agent among the known phytoestrogens $[7,8,10]$.

The process chain for obtaining APIs of the plant origin consists of different sets of operations performed according to the specific technological modes. Based on thermolabile properties of most substances of the plant origin the development of the technology for obtaining the corresponding APIs requires the study of dependence of the composition at each process stage involving heating of the product.

The aim was to study the influence of temperature parameters of evaporation and drying processes of the hop liquid extract on the content of xanthohumol, isoxanthohumol, 8-prenylnaringenin and 6-prenylnaringenin in the dry extract.

The results obtained should become an important factor in development of technology for obtaining the hop dry extract enriched in prenyl flavonoids as the promising API.

\section{Experimental Part}

The starting materials were hop cones of "Xantha" cultivar (the product of the Polissya Institute of Agriculture at the NAASU) harvested in 2012, $n$-hexane, ethanol and purified water. For cyclization of chalcones $\mathrm{X}$ and DMX to the corresponding flavanones IX, 8-PN and 6-PN the hop cones were pretreated by water steam for 1 hour. After thermal pretreatment the remaining moisture was removed from the raw material, and hop cones were extracted in two steps. All extraction steps were performed by the method of filtration extraction at the room temperature. At the first step the hop cones treated was extracted with $n$-hexane to the drug extract ratio (DER) of 1:12 with the subsequent removal of the residual extractant from the extraction cake [2]. At the second step the hop semi-product (the extraction cake) was extracted with $70 \%$ (vol.) ethanol to DER of 1:10. Removal of the solvent from the liquid extract and subsequent drying were conducted in a Büchi R134 rotary evaporator at the water-bath temperature $60-63^{\circ} \mathrm{C}$ and at the vacuum operating range of $80-38 \mathrm{mBar}$. Before drying of the liquid extract the dry residue content and the quantitative content of $\mathrm{X}, \mathrm{IX}, 8-\mathrm{PN}$ and 6-PN were determined and the yield of extractives in it was calculated. The quantitative content of X, IX, 8-PN та 6-PN was determined in the hop dry extract obtained.

The dry residue content in the samples was determined by the method according to the State Pharmacopeia of Ukraine [1].

The assay of X, IX, 8-PN та 6-PN in the hop dry extracts obtained was carried out by the liquid chromato- 
Table

Quantitative characteristics of the extracts obtained

\begin{tabular}{|l|c|c|}
\hline \multicolumn{1}{|c|}{ Criteria } & $\begin{array}{c}\text { Liquid } \\
\text { extract }\end{array}$ & $\begin{array}{c}\text { Dry } \\
\text { extract }\end{array}$ \\
\hline Xanthohumol (X), \% & 1.688 & 1.451 \\
\hline Isoxanthohumol (IX), \% & 0.412 & 0.345 \\
\hline 8-prenyInaringenin (8-PN), \% & 0.062 & 0.057 \\
\hline 6-prenyInaringenin (6-PN), \% & 0.208 & 0.179 \\
\hline Yield of extractives, \% & \multicolumn{2}{|c|}{24.55} \\
\hline
\end{tabular}

Note: the quantitative content of (X, IX, 8-PN, 6-PN) are calculated with reference to dried substance.

graphy method. In the assay the approach of determination of the given compounds using secondary standards was applied [4].

Chromatographic procedure was carried out in an Ultimate 3000 chromatograph with a UV detector at the temperature of $50^{\circ} \mathrm{C}$. As a mobile phase A $0.25 \%(\mathrm{v} / \mathrm{v})$ formic acid $R$ was used, and $0.25 \%(\mathrm{v} / \mathrm{v})$ formic acid $R$ in acetonitrile $R$ was used as a mobile phase $\mathrm{B}$. The chromatographic conditions were the following: the flow rate$1 \mathrm{~mL} / \mathrm{min}$; the column - Purospher STAR RP 18-e $(5 \mu \mathrm{m})$ $250 * 4.0 \mathrm{~mm}$; the injection volume $-20 \mu \mathrm{L}$; detection at $370 \mathrm{~nm}(\mathrm{X})$ and at $290 \mathrm{~nm}$ (IX, 8-PN, 6-PN). The gradient programme was $0 \mathrm{~min}, 80: 20$ (A:B); $3 \mathrm{~min}, 80: 20$; $3 \rightarrow 25 \mathrm{~min}, 60: 40 ; 25 \rightarrow 37 \mathrm{~min}, 60: 40 ; 37 \rightarrow 55 \mathrm{~min}, 40: 60$; $55 \rightarrow 56 \mathrm{~min}, 10: 90$. Determination of $X$ was carried out using quercetin, and determination of IX, 8-PN, 6-PN was performed using naringenin as secondary standards.

Identification of peaks was carried out using the same conditions in an Ultimate 3000 chromatograph with MS / MS detector and literature data [3].
The yield of the extractives from the raw material extracted was calculated as:

$$
D=\frac{\varpi \times V}{m}, \%,
$$

where: $\mathrm{V}$ - is the volume of the liquid extract, $\mathrm{ml} ; \omega-$ is a dry residue in the liquid extract, $\% ; \mathrm{m}-$ is the mass of the raw material used for extraction, $g$.

\section{Results and Discussion}

The hop prenyl flavonoids X, DMX, IX, 8-PN and 6-PN are relatively unstable compounds and under the certain thermodynamic conditions are capable to transform. In particular, chalcones X and DMX can be subjected to thermal isomerization, and it is confirmed by the conversion of $\mathrm{X}$ to IX during wort boiling in brewing $[5,6,9]$.

Obtaining of a dry extract is always associated with the use of high temperatures at the stages of evaporation and drying. The nature of the thermal effects on the quantitative content of $\mathrm{X}, \mathrm{IX}, 8-\mathrm{PN}$ and 6-PN was evaluated by the content of these compounds in the water-alcohol extract before its evaporation and in the dry extract obtained. In order to prevent possible destruction of prenyl flavonoids the evaporation and drying of hop cones extracts were carried out in vacuum under the sparing conditions appropriate for subsequent manufacturing-scale production. The data obtained are presented in Table.

The experimental data show decrease of the quantitative content of X, IX, 8-PN and 6-PN in the dry extract compared with the content of these compounds in the water-alcohol liquid extract by $14.04 \%, 16.26 \%, 8.06 \%$ and $13.94 \%$, respectively. It indicates the negative effect of evaporation and drying of the liquid extract on

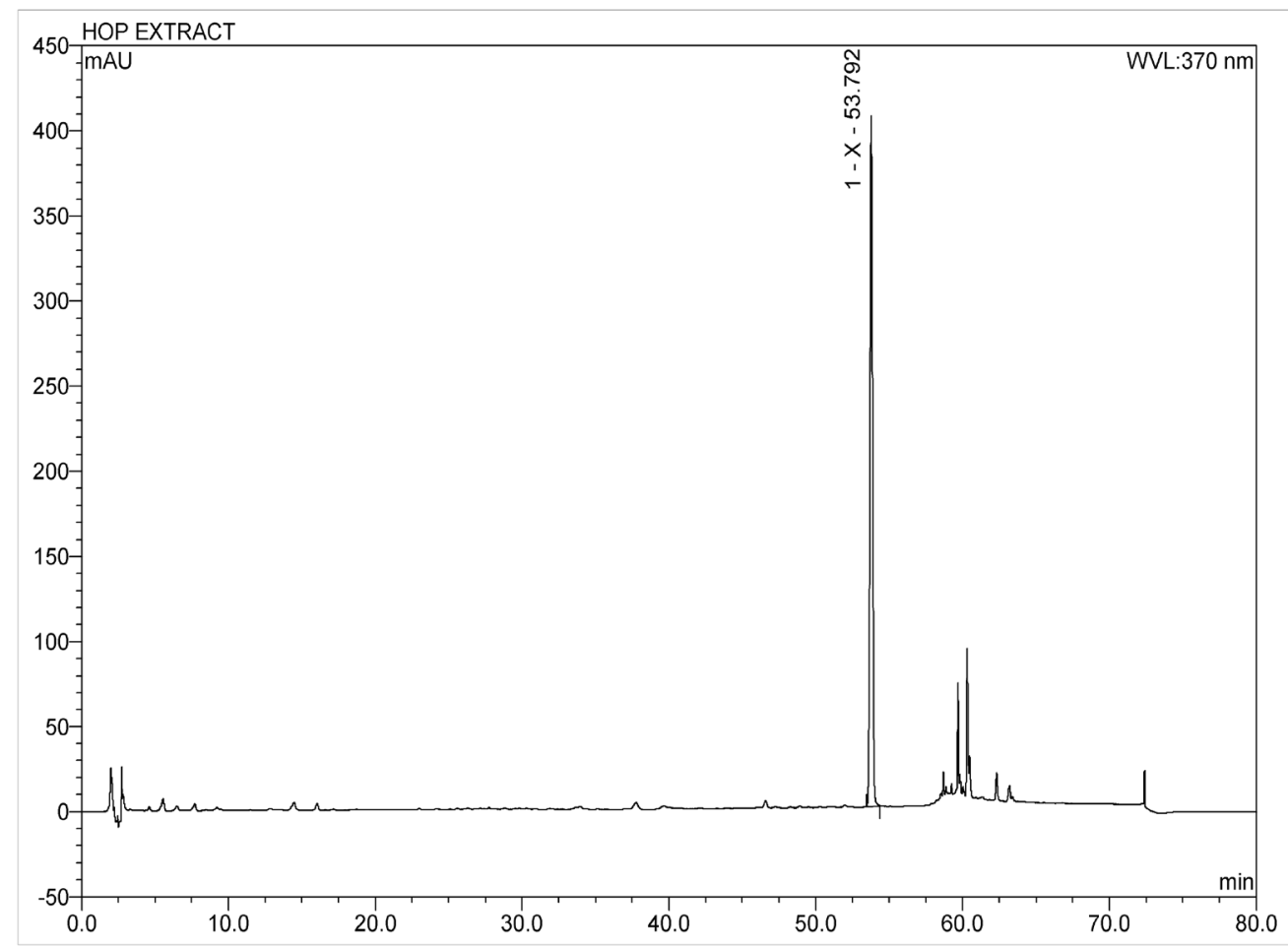

Fig. 1. The chromatogram of the hop water-alcoholic liquid extract at $370 \mathrm{~nm}$. 


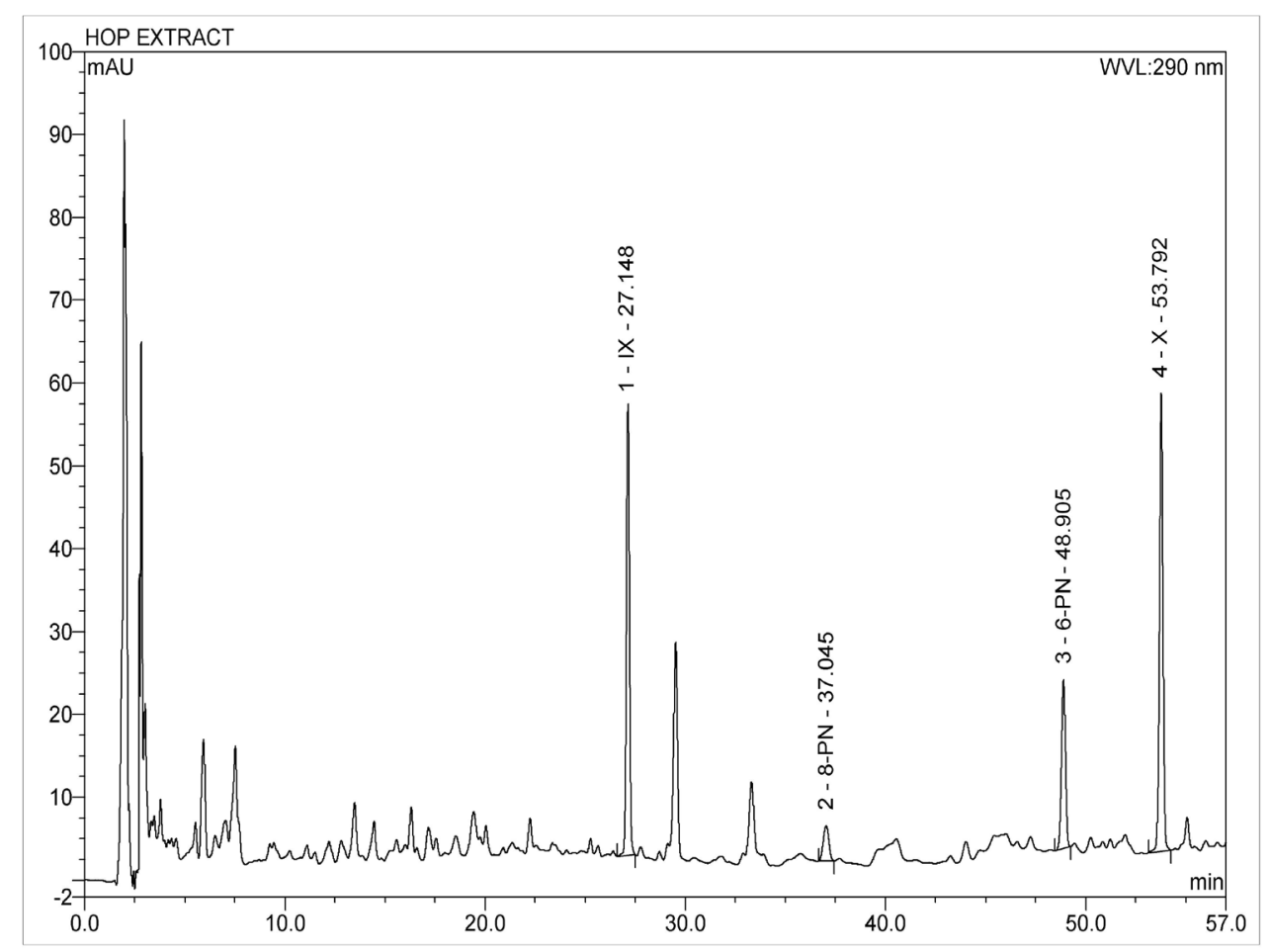

Fig. 2. The chromatogram of the water-alcoholic liquid extract at $290 \mathrm{~nm}$.

quantitative characteristics of the dry extract even with the sparing conditions applied with reduced boiling temperature in the vacuum environment. The chromatographic profiles of the samples are characterized by a similar set of major peaks and differ in their intensity decrease due to the aforementioned decrease in the quantitative content of $\mathrm{X}, \mathrm{IX}, 8-\mathrm{PN}$ and 6-PN in the dry extract obtained in com- parison with the water-alcohol liquid extract. Therefore, the temperature increase and/or decrease of the vacuum depth, i. e. parameters that can increase the boiling point in the process of evaporation and drying of the extract may lead to a greater reduction of the quantitative content of $X$, IX, 8-PN and 6-PN in the hop dry extract. The chromatograms of the test samples are presented in Fig. 1, 2, 3, 4.

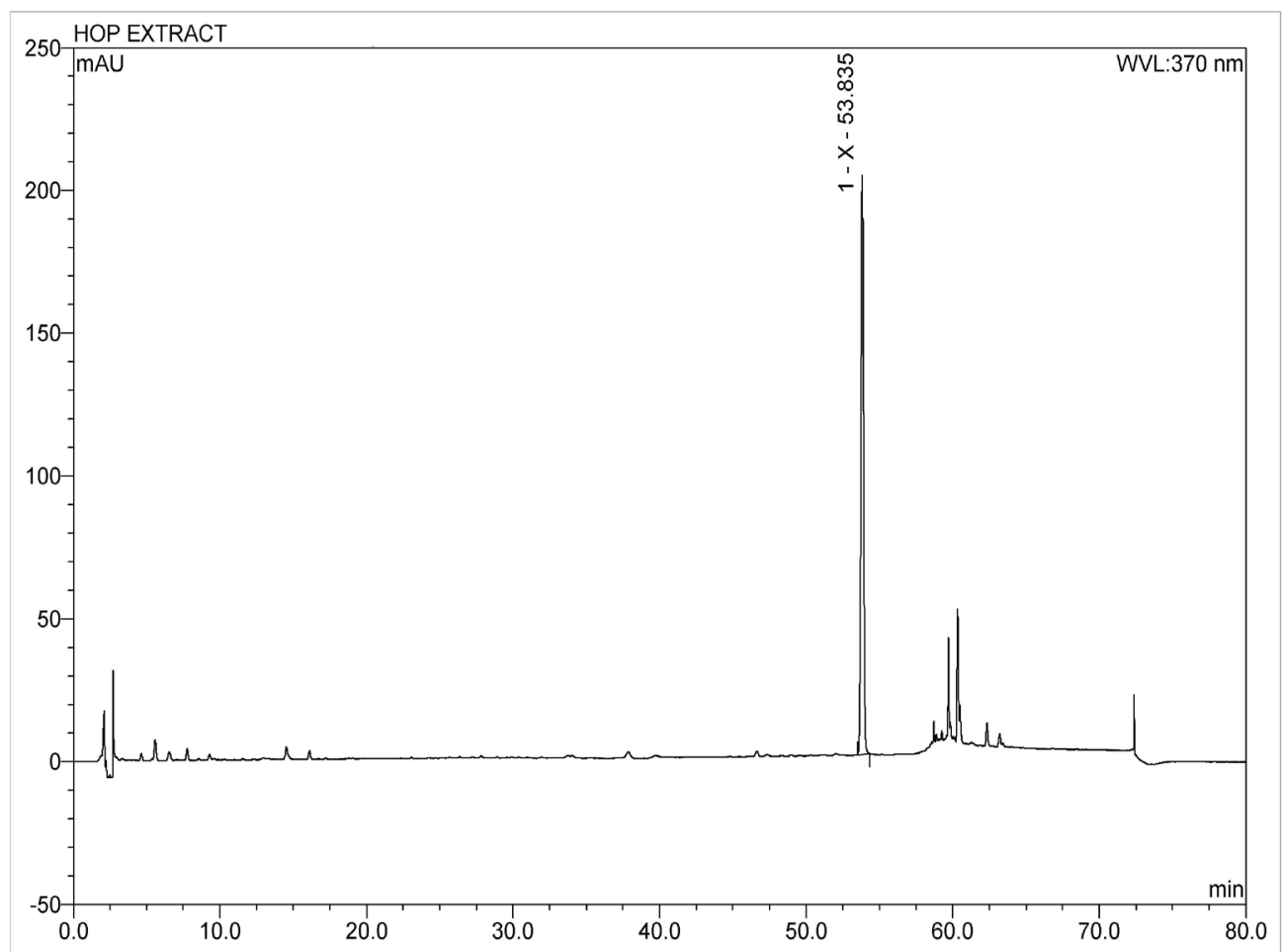

Fig. 3. The chromatogram of hop dry extract at $370 \mathrm{~nm}$. 


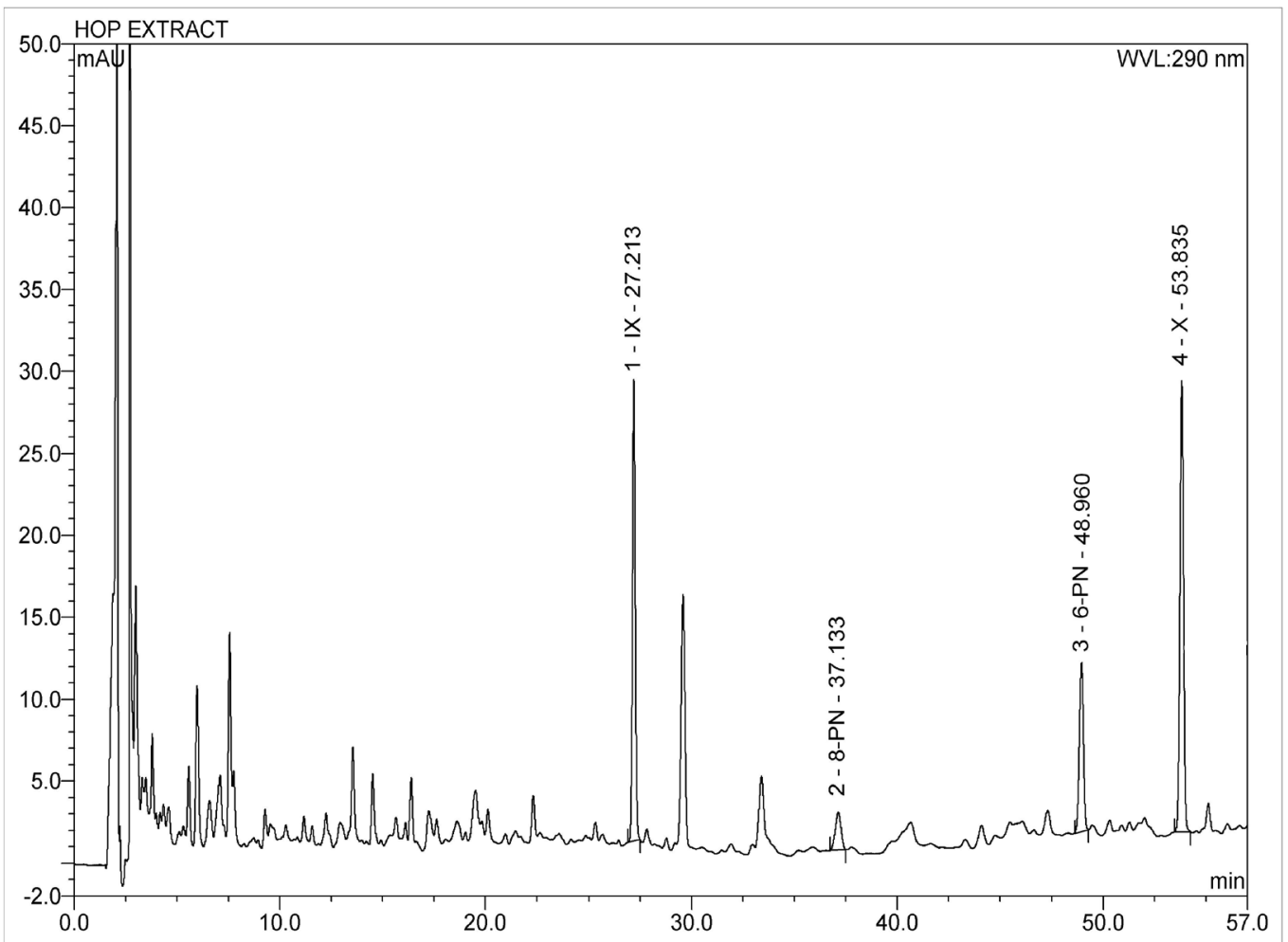

Fig. 4. The chromatogram of the hop dry extract at $290 \mathrm{~nm}$.

\section{CONCLUSIONS}

1. For the first time the influence of temperature parameters at the stages of evaporation and drying of the hop cones liquid extract on the quantitative content of xanthohumol, isoxanthohumol, 8-prenylnaringenin and 6-prenylnaringenin in the dry extract has been investigated.
2. It has been found that obtaining of the hop cones dry extract as a finished product provides the loss of the quantitative content of these prenyl flavonoids in the technological process.

3. The research results will be considered in the further development of the production process of the hop dry extract as the API.

\section{REFERENCES}

1. Державна фармакопея Украйни / Державне підприємство «Науково-експертний фармакопейний центр». 1-е вид. - Х: Державне підприємство «Науково-експертний фармакопейний центр», 2004. - Доп. 1. $520 \mathrm{c.}$

2. Шматенко О.П., Добровольний О.О., Савицький В.Л., Страшний В.В. Вивчення умов екстрагування речовин ліпофільної природи з суплідь хмелю // Проблеми військової охорони здоров'я. Зб. наук. прачь Украйнської військово-медичної академії. - К.: Украӥнська військово-медична академія, 2013. - Вип. 40. C. 282-289.

3. Ceslova L., Holcapek M., Fidler M. et al. // J. of Chrom. A. - 2009. - Vol. 1216. - P. 7249-7257.

4. Dhooghe L., Naessens T., Heyerick A. et al. // Talanta. - 2010. - Vol. 83, Iss. 2. - P. 448-456.

5. Karabin M., Jelinek L., Kinčl T. et al. // J. Inst. Brew. - 2013. - Vol. 119. - P. 98-102.

6. Krofta K. // Kvasny Prum. - 2010. - Vol. 56, Iss. 1. - P. 2-9.

7. Milligan S., Kalita J., Pocock V. et al. // Reproduction. - 2002. - Vol. 123, Iss. 2. - P. 235-242.

8. Milligan S.R., Kalita J.C., Pocock V. et al. // J. Clin. Endocrinol. Metab. - 2000. - Vol. 85, Iss. 12. - P. 4912-4915.

9. Possemiers S., Heyerick A., Robbens V. et al. // J. Agric. Food Chem. - 2005. - Vol. 53. - P. 6281-6288.

10. Schaefer O., Hümpel M., Fritzemeier K.H. et al. // J. Steroid. Biochem. and Mol. Biol. - 2003. - Vol. 84, Iss. 2-3. P. 359-360. 
ДОСЛІДЖЕННЯ ЗАЛЕЖНОСТІ ВМІСТУ ПРЕНІЛОВИХ ФЛАВОНОЇДІВ У СУХОМУ ЕКСТРАКТІ ХМЕЛЮ ВІД ТЕМПЕРАТУРНИХ ПАРАМЕТРІВ ПРОЦЕСУ ЙОГО ОДЕРЖАННЯ

\section{О.О.Добровольний}

Ключові слова: супліддя хмелю; екстрактивні речовини; пренілові фрлавоноїди; естрогенна активність; упарювання; сушка

У процесі розробки технології одержання сухого екстракту суплідь хмелю в якості АФІ з естрогеноподібною дією досліджували ключові фрактори, здатні впливати на якість готового продукту. Беручи до уваги те, що пренілові фрлавоноїди хмелю є відносно нестійкими сполуками та при певних термодинамічних умовах здатні до перетворень або деструкції, було досліджено вплив температурних параметрів упарювання та сушки рідкої витяжки хмелю на кількісний вміст ксантохумолу (X), ізоксантохумолу (IX), 8-пренілнарингеніну (8-PN) та 6-пренілнарингеніну (6-PN) в сухому екстракті. Об'єктами дослідження були зразки водно-спиртової витяжки, одержаної після екстрагування сировини та сухого екстракту після упарювання та сушки. Екстрагування суплідь хмелю здійснювали методом фрільтраційної екстракції в два ступені з попередньою термічною обробкою вихідної сировини водяною парою. На першому ступені сировину екстрагували н-гексаном, після чого на другому ступені проводили екстрагування шроту водно-спиртовим розчинником. 3 метою мінімізації можливої деструкції пренілових фрлавоноїдів одержану водно-спиртову витяжку упарювали та висушували у вакуумі. Кількісний вміст X, IX, 8-PN ma 6-PN в досліджуваних зразках визначали методом BEPX. Встановлено, що застосовані щадні умови упарювання та сушки привели до зниження кількісного вмісту $X, I X, 8-P N$ ma 6-PN в сухому екстракті порівняно з їх вмістом у водно-спиртовій витяжці в межах 14, 16, 8, 14\% відповідно.

\section{ИССЛЕДОВАНИЕ ЗАВИСИМОСТИ СОДЕРЖАНИЯ ПРЕНИЛОВЫХ ФЛАВОНОИДОВ В СУХОМ ЭКСТРАКТЕ ХМЕЛЯ ОТ ТЕМПЕРАТУРНЫХ ПАРАМЕТРОВ ПРОЦЕССА ЕГО ПОЛУЧЕНИЯ \\ А.А.Добровольный}

Ключевые слова: соплодия хмеля; экстрактивные вещества; прениловые фрлавоноиды; эстрогенная активность; упаривание; сушка

В процессе разработки технологии получения сухого экстракта соплодий хмеля в качестве АФИ с эстрогеноподобным действием исследовали ключевые факторы, способные влиять на качество готового продукта. Учитывая то, что прениловые фрлавоноиды хмеля являются относительно нестабильными соединениями и при определенных термодинамических условиях склонны к превращениям или деструкции, было исследовано влияние температурных параметров упаривания и сушки жидкого извлечения хмеля на количественное содержание ксантохумола $(X)$, изоксантохумола (IX), 8-пренилнарингенина (8-PN) и 6-пренилнарингенина (6-PN) в сухом экстракте. Объектами исследования были образцы водно-спиртового извлечения, полученного после экстрагирования сырья и сухого экстракта после упаривания и сушки. Экстракцию соплодий хмеля проводили методом фрильтрационной экстракции в две ступени с предварительной обработкой сырья водяным паром. На первой ступени сырье экстрагировали н-гексаном, после чего на второй ступени проводили экстракцию шрота водно-спиртовым растворителем. С целью минимизации возможной деструкции прениловых фрлавоноидов полученное водно-спиртовое извлечение упаривали и сушили в вакууме. Количественное содержание $X, I X, 8-P N$ и 6-PN в исследуемых образцах определяли методом ВЭЖХ. Установлено, что использованные щадящие условия упаривания и сушки привели к снижению количественного содержания $X$, IX, 8-PN и 6-PN в сухом экстракте в сравнении с содержанием в водно-спиртовом извлечении в пределах 14, 16, 8, 14\% соответственно. 